\title{
Laurent Joubert of Montpellier (1529-82) and his Erreurs Populaires
}

\author{
Peter M Dunn
}

Laurent Joubert was born on 16 December 1529 in the old province of Dauphine in southcentral France. He was the tenth of 20 children born to Le Chevalier Joubert and his wife, Catherine de Genas, between 1519 and 1541. Educated in his home town, he became at the age of 21 a student of Guillaume Rondelet, Chancellor of the Faculty of Medicine in the University of Montpellier. Even before receiving his doctorate of medicine in 1558 he had acquired the reputation of being an excellent teacher; on the death of Rondelet in 1556 he was, at the popular request of the students, appointed regent, and shortly afterwards, Chancellor of the Faculté. In this capacity he caught the attention of Catherine de Medici, who appointed him her personal physician. He also became one of the king's physicians (fig 1).

Joubert wrote a number of medical books in French as well as in Latin, of which undoubtedly the most important was his Popular Errors, the first part of which was published in 1577 . Recently it has been translated and annotated by Professor de Rocher of Alabama. ${ }^{1}$ In this book Joubert not only attempted to correct current misconceptions but at the same time

\section{Department of Child Health \\ Bristol University Southmead Hospital Southmead Bristol BS10 5NB P M Dunn}

Correspondence to: Professor Peter Dunn

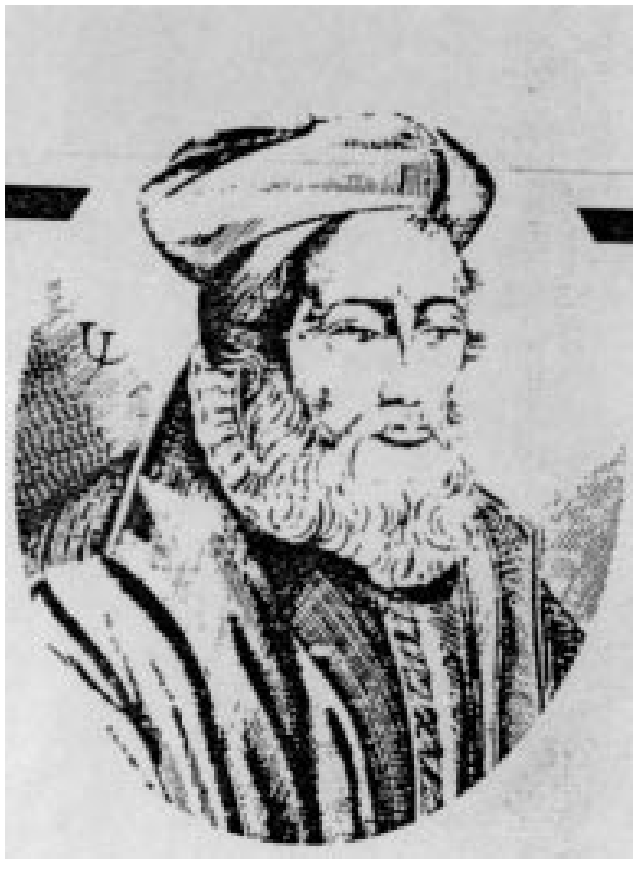

Figure 1 Laurent foubert (an artist's impression). boost the prestige of the physicians at the expense of other practitioners such as the barber-surgeons, apothecaries, and midwives. $\mathrm{He}$ also wrote about sexual matters that were considered taboo and in the province of women. The book caused a storm of protest. Joubert defended himself in an open letter to the Queen of Navarre, claiming that in addressing subjects such as conception and the diagnosis of virginity he was only discussing normal body functions. Still, the second edition, in 1579, was recommended reading only for those that were married!

Although some of Joubert's explanations of false popular beliefs were themselves incorrect, his book contains many fascinating insights into medical attitudes in the sixteenth century and not a little wise advice relevant to our own times, as the following extracts reveal.

\section{On multiple pregnancy}

"A woman has only two mammae and can thus carry only two children ordinarily and nourish the same number. For if she has three or four at a time ... they will not live communally; ill nourished in their mother's belly, and thus unable even to endure the strain of coming out, they (may) die in the birth passage or soon afterward ... such children are borne only for a period of seven months ... This is because the womb had slightly stretched ... it is enough that they are well formed and have all the parts needed by the nutritive faculty. They recover well from their fasting and abstinence if they find proper nurses who give them lots of milk. They make more progress in eight days than others who are born well nourished do in three weeks. Everyday we see very small ones born, all withered and wrinkled like an old apple, who in almost no time become marvellously big and fat."

\section{On the amniotic fluid}

"... when a woman is about to deliver she lets out a lot of water ... this water comes from the womb and is urine for the most part but it is the child's, and not the mother's. This water was retained and held in the skin of the secundine, which, breaking open when the little one comes out of it, lets this water flow out and helps to make the passageway more slippery." 


\section{On posture in childbirth}

"It is now necessary to consider various postures during the act of childbirth. Some wish to be standing, held up, others, seated on a sawed-out chair that is also open in the front; still others, lying down. I let those who have tried everything choose the manner they find the easiest. I only warn that they be certain that the crupper is free and unimpeded, so that it is able to flex down freely. This would be aided tremendously if the standing method were used at just the right time, when the child starts coming out, without tiring the poor woman or causing her useless pain. For besides the fact that the crupper (as it is called) has great freedom of movement in such a posture, the child, because of its own weight, descends better and aids its delivery ... It is a thing of great importance to have the woman deliver comfortably ..."

\section{On breastfeeding and bonding}

"Only an unnatural, imperfect, and halfhearted mother would have a child and then suddenly reject it and send it away. What sort of woman would nourish in her womb with her very blood a being she could not see and then not nurse with her milk one she could see, alive and expecting its mother to do her duty? Do you think nature gave women nipples on their breasts to serve as pretty little buttons for embellishment rather than for the nursing of their children? Are these women not prodigal when they work at stopping and drying up these most sacred fountains of the body, wellsprings of the human species ... as if it disfigured the marks of their beauty? ... mothers who thus abandon and turn out their children, giving them to others to be nursed, sever the bond and tie of love, by which nature joins fathers and mothers to their children, or at least loosen and weaken this link ... One of a woman's greatest desires is to find herself pregnant and then graced with a beautiful birth. How can she suddenly be so inconstant and fickle that, scarcely does the child see the light of day, she rids herself of it, sending it away to be nursed by a strange woman? ... Without a doubt, the love and the pleasure are double with mothers who nurse their children ...”

\section{On cracked nipples}

"Tandrieres are little fissures in the ... nipples of the breasts, when they crack and split because of the first milk, especially in those who nurse, because as the child sucks and pulls on them they split all the more ... Now, in order to avoid them, especially right from the first child, women apply diverse remedies, all of which tend toward exsiccation, thinking that by correcting the softness one will prevent such little splits, inasmuch as the nipple that is already hardened is not going to be so subject to them ... And all these do nothing but make the nipples much worse, for the harder and stiffer the nipples are, the more they will split. The very opposite is what must be done: soften them and make them supple before the milk arrives. For if they are soft, they will definitely give enough and will not split ... This is why those who are better informed will apply to their nipples some new wax thinned with some soft oil a few months before delivering in order to avoid tandrieres. But it is better yet, as I prescribe, to grease them often with cool bacon fat, which softens them nicely and gently."

\section{On fixed times for feeding babies}

"Women are of the opinion that in order to give a child proper care it must be regulated according to fixed hours, both for nursing as well as for changing its breechcloth to keep it clean ... whoever would seek to limit the feedings of all children to the same times cannot fail upsetting nearly all of them ... the child that is fed on an individual basis will be far healthier ... And so it seems it would be better to make another rule: namely, that the child not have any fixed and limited timetable, but that the nurse give it her breast constantly. For if it is hungry, it will suck; it not, it will abstain ...”

\section{On relactation}

"A poor woman died, leaving her five- or sixmonth-old child without a nurse. Her niece, verily a young girl and a virgin, a plump child and in good health, tried a few times to calm the child (which was dying of hunger) by offering it her breasts as if there were milk in them. The child so pulled and drew on them that it made some bloodied humour come out, which the poor girl endured patiently in order to please her little cousin on whom she had pity. This went on so much that the red turned to white and became milk, with which she eventually nursed the child for more than a year..."

Joubert married Louise de Guichard and between 1565 and 1577 she gave birth to, and breastfed, three sons and three daughters. $\mathrm{He}$ lived to the age of 53, dying on 21 October 1582. It is said that he was called out on a stormy night to see a patient in the small village of Lombers, near Montpellier and failed to return.

1 Joubert, L. Popular errors. Translated by GD de Rocher. Tuscaloosa and London: University of Alabama Press, 1989. 